\title{
PREPARATION OF LOW COST SHOE SOLING MATERIAL FROM LEATHER WASTE
}

\author{
S.Ponsubbiah ${ }^{1} \&$ Dr.Sanjeev Gupta ${ }^{2}$ \\ ${ }^{1}$ Institute of Leather Technology \& ${ }^{2}$ CSIR-CLRI
}

\begin{abstract}
Sole is the bottom component of footwear and it protects our feet from heat and other sharp objects. The roles of polymers are very important in the production of footwear. Abrasion résistance, sole flexing, hardness, Tensile strength, density \& Thermal stability are the important properties required for soling materials. Some common soling materials used in footwear making are
\end{abstract}

1. Leather (sole leather)

2. Rubber (NBR, SBR, Isoprene, Microcellular rubber\& crepe rubber)

3. PVC (Poly vinyl chloride)

4. TPR (Thermoplastic rubber)

5. PU (Poly urethane)

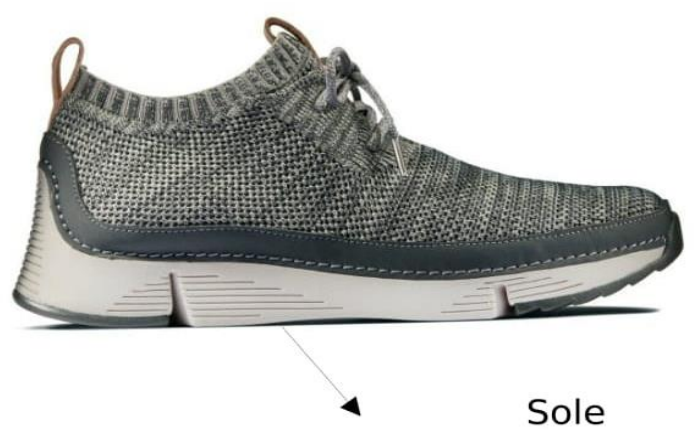

In our research in the previous study soling materials were prepared using chrome shaving (tannery solid waste), EPDM, isoprene rubber with three different types of commercial nano fillers namely SI, KLN, BNT .Out of these three trial soling material made using KLN (clay based) nano fillers exhibits good Physical and Mechanical properties. In this study the soling materials were prepared using EPDM, isoprene rubber, KLN nano filler with different proposition(50 Phr to $100 \mathrm{Phr}$ ) of pre treated chrome shaving (tannery solid waste). This research fully focus on reduce the solid waste generated by leather industry by utilising them as a low cost shoe soling material.

\section{INTRODUCTION}

Leather processing involves discharge of enormous quantities of liquid and solid wastes. While efficient recycling methods and in-plant controls have considerably reduced the discharge of obnoxious liquid streams, satisfactory methods to the solid waste management still elude the leather manufacturers. Land-filling is an easy option for the disposal of solid wastes like chrome shavings and trimmings, but is subjected to stringent environmental regulations because of the presence of chromium in these materials. Considerable efforts have been made to recycle the chrome containing wastes by methods such as incineration, pyrolysis and alkaline or enzyme hydrolysis. These recycling processes, however, are seldom complete without further environmental problems. Unfortunately, in such recycling processes the inherent fibrous structure of these materials gets completely destroyed.

Applications based on the fibrous nature of the shavings and trimmings are presently limited but various possibilities are being explored continuously. An efficient way of utilization of these fibrous waste materials may be to combine them in a suitable form with synthetic polymers to give composite materials. Short fiber reinforcement of polymersis an important area in polymer composites where both synthetic and natural fibers are effectively used. Such applications based on the fibrous nature of the chrome shavings and trimmings would circumvent the environmental problem as well as evolve value added products based on these waste materials.

\subsection{Materials}

The following materials were used for development of shoe soling material from Leather waste (Chrome shaving).

\begin{tabular}{|l|c|}
\hline \multicolumn{1}{|c|}{ Name of the material } & Role of the material \\
\hline Isoprene rubber & Base polymer \\
\hline Chrome shaving & Solid waste/filler \\
\hline Zinc oxide & Activator \\
\hline Stearic acid & Activator \\
\hline CBS & Accelerator \\
\hline MBTS & Accelerator \\
\hline TMT & Accelerator \\
\hline SULPHUR & Vulcanising Agent \\
\hline KLN & Nano filler \\
\hline
\end{tabular}

\subsubsection{Isoprene Rubber}

Isoprene $\left(\mathrm{C}_{5} \mathrm{H}_{8}\right)$ is a widely-used polar rubber and economical commercial rubber. We can harvest isoprene from rubber trees (NR) as latex and also we can produce it synthetically by polymerization. Natural rubber comes under the category of non-synthetic rubber. In the beginning of the 20 th century it has been commercialised. The structure of isoprene is mentioned below 
<smiles>CCC(C)CCC(C)CC(C)CC</smiles>

\subsubsection{EPDM Rubber (Ethylene Propylene Diene} Monomers)

EPDM is also a synthetic polar rubber with high density and able to withstand high temperatures up to $130^{\circ} \mathrm{C}$. As such, we can used for things such as window and door seals or waterproofing sheets.It has good scrape, cut growth and tear resistance. The structure of EPDM rubber is shown below

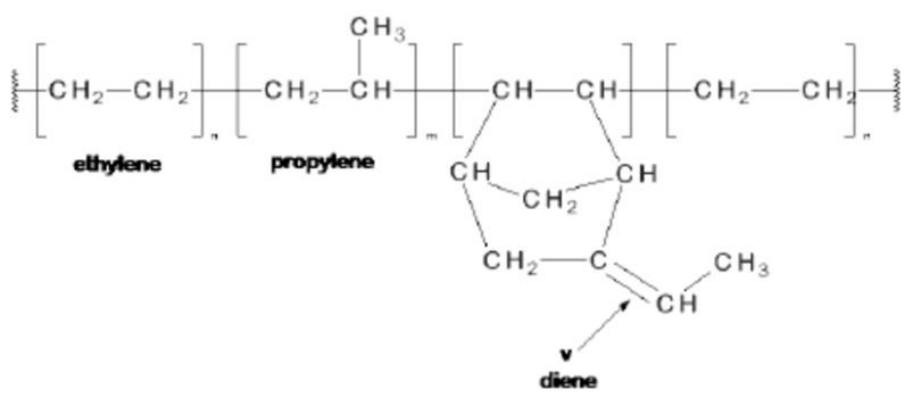

\subsubsection{Chrome shavings}

Chrome shavings are derived when the wet blue leathers are subjected in shaving operation in order to reduce thickness desirable thickness Chrome shavings are tiny, thin and fibre protein material This is harmful waste category and across the country about $35 \%$ of the total tannery waste are generated during leather processing as trimmings and chrome shavings. Every year about 20000 tones of chrome shavings are generated in india. Chrome shavings alone constitute to an extent of $10 \%$ of the total weight of raw Hides/Skins.

\subsubsection{KLN Nano fillers}

Fillers are the materials that are added to a polymer formulation to lower the compound cost or to improve properties. They can be in the form of solid, liquid or gas. Suitable selection of these materials can improve not only the economics but also the other properties such as processing and mechanical behaviour. The fillers also require a balance of formulation for optimum processing properties. In this research clay based nano filler are used and also it is commercially available (manufactured by alpha chemist India Ltd) in the market.

\section{PRETREATMENT OF CHROME SHAVINGS}

The shavings were collected from Viralli Enterprises, Chennai-44 and it was subjected to pretreatment. Normally chrome tanned leathers are acidic in nature and in order to neutralisation it was treated with $2 \%$ of Ammonia Solution and 2\% of Alkaline salt (Sodium bi carbonate).After the pre treatment the shavings were dried in sun light for 48 hours and then it was passed in the strap cutting machine to reduce the length.

\section{CHARACTERIZATION OF CHROME} SHAVINGS

The pre-treated chrome shavings were tested for various characterisations as mentioned below.

\begin{tabular}{|l|c|}
\hline \multicolumn{1}{|c|}{ Tests } & Values \\
\hline PH in water Extract $(w t \%)$ & $4.15 \pm 0.20$ \\
\hline Chrome Oxide $(w t \%)$ & $3.41 \pm 0.10$ \\
\hline Nitrogen $(w t \%)$ & $9.71 \pm 1.41$ \\
\hline Protein $(w t \%)$ & $54.58 \pm 3.80$ \\
\hline Decomposition Temperature $\left({ }^{\circ} \mathrm{C}\right)$ & $323.0 \pm 10.0$ \\
\hline Diameter Average $(\mu \mathrm{m})$ & $4.52 \pm 0.03$ \\
\hline Length Average $(\mu \mathrm{m})$ & $258.5 \pm 2.50$ \\
\hline
\end{tabular}

\section{MACHINERY}

A. Two roll mill( roller dimension $\mathrm{D}=220 \mathrm{~mm}$ and Length $\mathrm{L}=450 \mathrm{~mm}$ )

B. Strap cutting machine(for chrome shaving fibre length reduction)

C. Compression moulding machine

\section{EXPERIMENTS}

The homogeneous rubber mixes were prepared by using a two roll mill. The following parameters were considered at the time of compounding process

1. Temperature of the rolls $303-312 \mathrm{~K}$.

2. Roll speed $\mathrm{Vo}_{\mathrm{O}}=16 \mathrm{rpm}$.

3. Pressure $160 \mathrm{~kg} / \mathrm{cm}^{2}$

4. Height of the die $8 \mathrm{~mm}$

Then it was stored at temperature 275-312 K.

\subsection{Control}

Commercially available vulcanised rubber materials are used as a control in this research. ( manufactured by Shalimar soles Pvt Ltd.)

\subsection{Trial 1- (T1) -Control}

The following compounding materials were used in this trial

\begin{tabular}{|l|c|}
\hline \multicolumn{1}{|c|}{ Name of the material } & Quantity \\
\hline Isoprene rubber & $50 \mathrm{Phr}$ \\
\hline EPDM Rubber & $50 \mathrm{Phr}$ \\
\hline Chrome shaving & $50 \mathrm{Phr}$ \\
\hline Zinc oxide & $10 \mathrm{Phr}$ \\
\hline Stearic acid & $4 \mathrm{Phr}$ \\
\hline CBS & $1 \mathrm{Phr}$ \\
\hline MBTS & $1 \mathrm{Phr}$ \\
\hline TMT & $0.5 \mathrm{Phr}$ \\
\hline SULPHUR & $5 \mathrm{Phr}$ \\
\hline Nano Filler KLN & $10 \mathrm{Phr}$ \\
\hline
\end{tabular}

During this compounding process in order to get the uniform compounding proper nip cap and cuts were maintained

5.3. Trial 2- (T2)

The following compounding materials were used in this experiment

\begin{tabular}{|l|c|}
\hline \multicolumn{1}{|c|}{ Name of the material } & Quantity \\
\hline Isoprene rubber & $50 \mathrm{Phr}$ \\
\hline EPDM Rubber & $50 \mathrm{Phr}$ \\
\hline Chrome shaving & $60 \mathrm{Phr}$ \\
\hline Zinc oxide & $10 \mathrm{Phr}$ \\
\hline
\end{tabular}




\begin{tabular}{|l|c|}
\hline Stearic acid & $4 \mathrm{Phr}$ \\
\hline CBS & $1 \mathrm{Phr}$ \\
\hline MBTS & $1 \mathrm{Phr}$ \\
\hline TMT & $0.5 \mathrm{Phr}$ \\
\hline SULPHUR & $5 \mathrm{Phr}$ \\
\hline Nano Filler KLN & $10 \mathrm{Phr}$ \\
\hline
\end{tabular}

During this compounding process in order to get the uniform compounding proper nip cap and cuts were maintained

5.4. Trial 3- (T3)

The following compounding materials were used in this experiment

\begin{tabular}{|l|c|}
\hline \multicolumn{1}{|c|}{ Name of the material } & Quantity \\
\hline Isoprene rubber & $50 \mathrm{Phr}$ \\
\hline EPDM Rubber & $50 \mathrm{Phr}$ \\
\hline Chrome shaving & $70 \mathrm{Phr}$ \\
\hline Zinc oxide & $10 \mathrm{Phr}$ \\
\hline Stearic acid & $4 \mathrm{Phr}$ \\
\hline CBS & $1 \mathrm{Phr}$ \\
\hline MBTS & $1 \mathrm{Phr}$ \\
\hline TMT & $0.5 \mathrm{Phr}$ \\
\hline SULPHUR & $5 \mathrm{Phr}$ \\
\hline Nano Filler KLN & $10 \mathrm{Phr}$ \\
\hline
\end{tabular}

During this compounding process in order to get the uniform compounding proper nip cap and cuts were maintained

5.5. Trial 4- (T4)

The following compounding materials were used in this experiment

\begin{tabular}{|l|c|}
\hline \multicolumn{1}{|c|}{ Name of the material } & Quantity \\
\hline Isoprene rubber & $50 \mathrm{Phr}$ \\
\hline EPDM Rubber & $50 \mathrm{Phr}$ \\
\hline Chrome shaving & $80 \mathrm{Phr}$ \\
\hline Zinc oxide & $10 \mathrm{Phr}$ \\
\hline Stearic acid & $4 \mathrm{Phr}$ \\
\hline CBS & $1 \mathrm{Phr}$ \\
\hline MBTS & $1 \mathrm{Phr}$ \\
\hline TMT & $0.5 \mathrm{Phr}$ \\
\hline SULPHUR & $5 \mathrm{Phr}$ \\
\hline Nano Filler KLN & $10 \mathrm{Phr}$ \\
\hline
\end{tabular}

During this compounding process in order to get the uniform compounding proper nip cap and cuts were maintained

5.6. Trial 5- (T5)

The following compounding materials were used in this experiment

\begin{tabular}{|l|c|}
\hline \multicolumn{1}{|c|}{ Name of the material } & Quantity \\
\hline Isoprene rubber & $50 \mathrm{Phr}$ \\
\hline EPDM Rubber & $50 \mathrm{Phr}$ \\
\hline Chrome shaving & $90 \mathrm{Phr}$ \\
\hline Zinc oxide & $10 \mathrm{Phr}$ \\
\hline Stearic acid & $4 \mathrm{Phr}$ \\
\hline CBS & $1 \mathrm{Phr}$ \\
\hline MBTS & $1 \mathrm{Phr}$ \\
\hline TMT & $0.5 \mathrm{Phr}$ \\
\hline SULPHUR & $5 \mathrm{Phr}$ \\
\hline Nano Filler KLN & $10 \mathrm{Phr}$ \\
\hline
\end{tabular}

During this compounding process in order to get the uniform compounding proper nip cap and cuts were maintained
The following compounding materials were used in this experiment

\begin{tabular}{|l|c|}
\hline \multicolumn{1}{|c|}{ Name of the material } & Quantity \\
\hline Isoprene rubber & $50 \mathrm{Phr}$ \\
\hline EPDM Rubber & $50 \mathrm{Phr}$ \\
\hline Chrome shaving & $100 \mathrm{Phr}$ \\
\hline Zinc oxide & $10 \mathrm{Phr}$ \\
\hline Stearic acid & $4 \mathrm{Phr}$ \\
\hline CBS & $1 \mathrm{Phr}$ \\
\hline MBTS & $1 \mathrm{Phr}$ \\
\hline TMT & $0.5 \mathrm{Phr}$ \\
\hline SULPHUR & $5 \mathrm{Phr}$ \\
\hline Nano Filler KLN & $10 \mathrm{Phr}$ \\
\hline
\end{tabular}

During this compounding process in order to get the uniform compounding proper nip cap and cuts were maintained

\section{CURING}

Pre - heated mould which maintained at $140^{\circ} \mathrm{C}$ $160^{\circ} \mathrm{C}$ for 5 to 12 minutes to get cured sample by compression moulding machine. Matching male and female mould halves were used in this process. A pre-weighed charge cut to the size is placed inside the mould.. The applied temperature and pressure force the material to fill the mould cavity and facilitate polymerization (or crosslinking) and consolidation of composite material. The curing time and temperature of these samples were calculated and noted.

\section{CHARACTERISATION}

\subsection{Physical Testing}

Required test specimens were punched out from the prepared soling material using die. Mechanical properties such as tensile strength, percentage of elongation at break, abrasion resistance, sole flexing endurance and hardness were measured in CLRI laboratory.

The results are shown in the Table. 

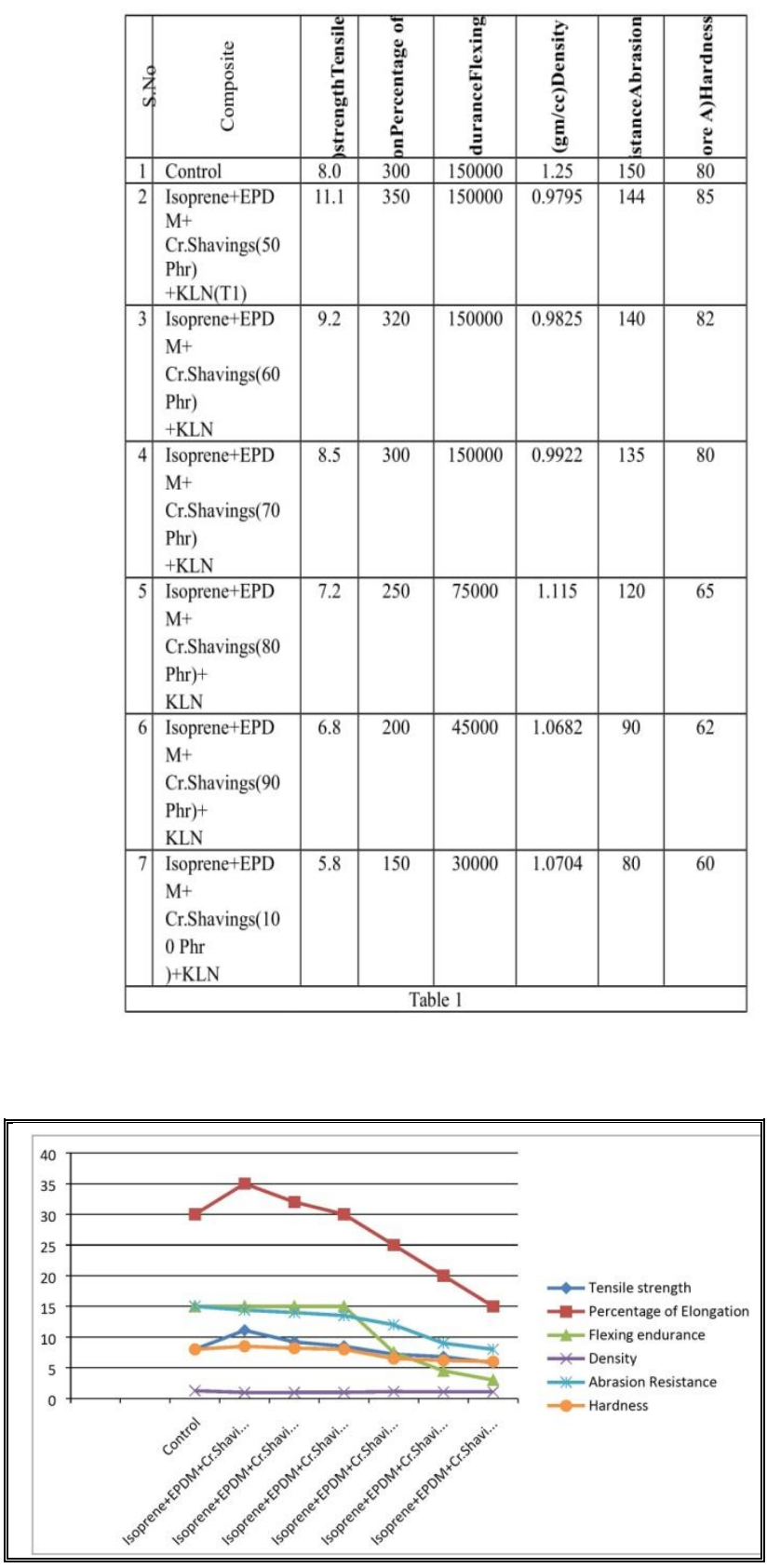

Chart 1

\subsection{IR-Spectroscopy}

KBR pellets (500mg) each containing 2-6mg of the sample, were prepared for IR spectroscopy. The IR spectra of the sample were then taken using a Nicolet impact 400 FTIR spectroscope. The following condition were followed and the results are shown in the below Figures

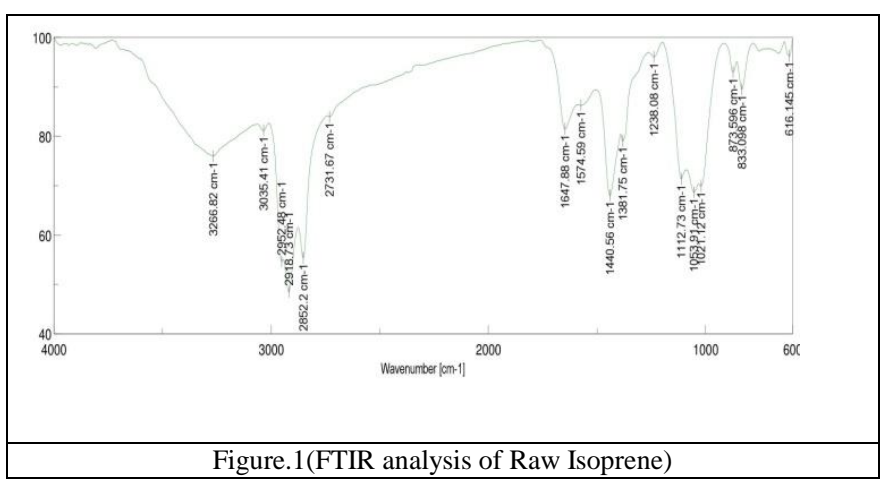

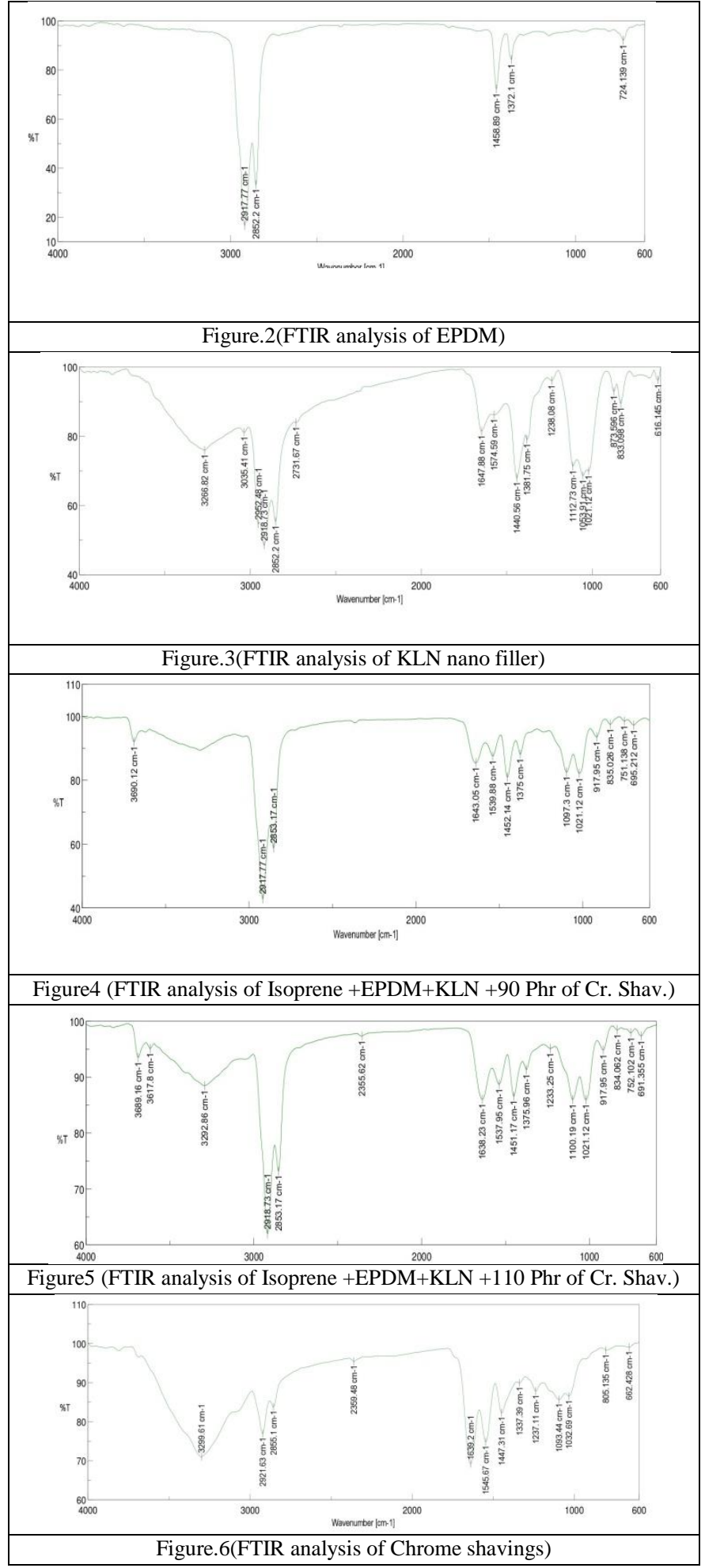

\subsection{Scanning Electron Microscopy (SEM)}

The SEM Micrographs (500X) of the fractured surfaces of the tensile tested specimens were taken using S150 stereo scan model. In order to provide visual data, to support the physico mechanical behaviour of the four polymeric compositions tensile fractured surfaces of the specimens Isoprene /Cr. Shaving; EPDM/Cr. Shaving; Isoprene/EPDM/Cr. Shaving; were subjected to SEM Micrograph study. 


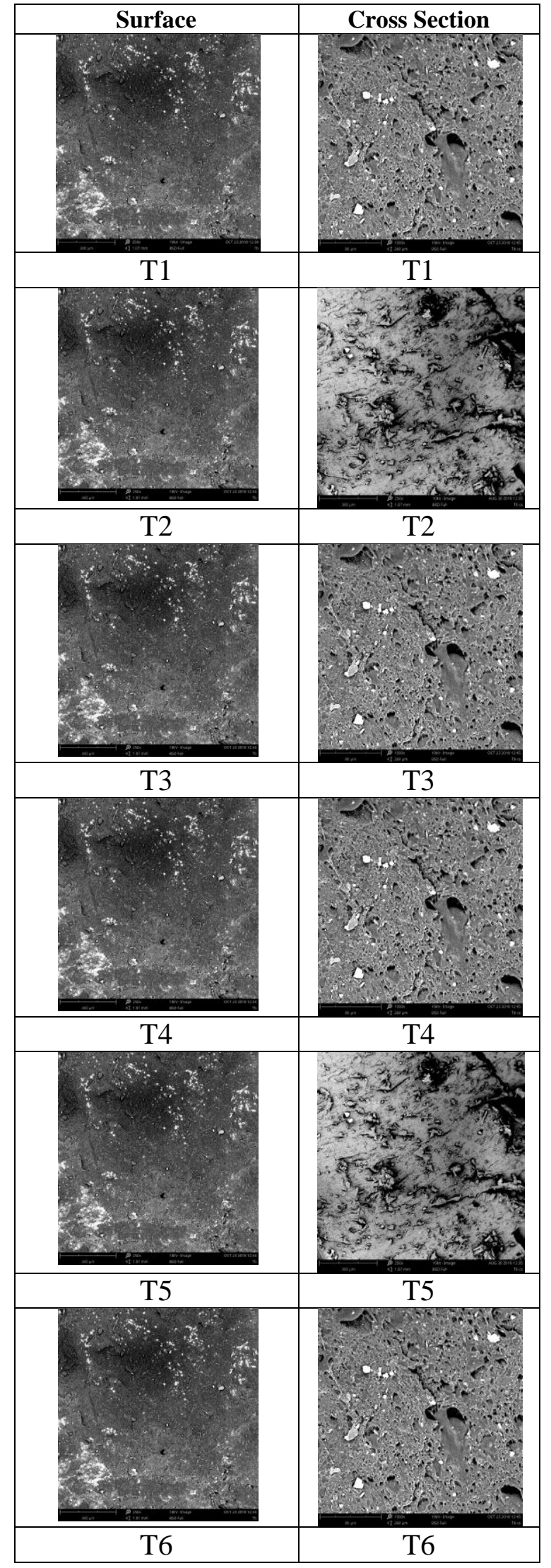

\section{RESULTS AND DISCUSSION}

\subsection{Mechanical Properties}

In our trials it is clear that good compatibility between Isoprene, EPDM, Chrome shavings and KLN nano filler, while adding different proportion of chrome shaving (70Phr to $100 \mathrm{Phr}$ ) there is a gradual decrease in mechanical properties such as tensile strength, Elongation to break and flexing endurance. But any have it is almost meet the control parameters while adding chrome shavings up to 70 Phr. The density and abrasion resistance of all composite is reasonably good.

\subsection{IR Spectroscopy}

The infrared spectra of the samples are shown in the above figures. Fig4 \& Fig5 show the amide absorption band around $1680 \mathrm{~cm}^{-1}$. Asorbtion band at $1025 \mathrm{~cm}^{-1}, 1120 \mathrm{~cm}^{-1}$ and $1130 \mathrm{~cm}^{-1}$ represent $\mathrm{OH}$ group in the samples. The spectra show multiple bands between $3250 \mathrm{~cm}^{-1}$ to $2530 \mathrm{~cm}$ ${ }^{1}$.Thus the IR spectra reveal the presence of leather fiber in the composite.

\subsection{Scanning Electron Microscopy}

The SEM images of the sample are shown in the above figure. While individual SEM image of sample T1,T2\&T3 shows individual fibres of chrome shavings without much aggregation. The SEM image of sample T5 and T6 shows aggregation of fiber due to blending of Isoprene and EPDM with $100 \mathrm{Phr}$ of chrome shavings. The SEM image reveals that in all three samples chrome shavings are intermingled with polymers and also can see that in all the three samples chrome shavings are closely knitted.

\section{CONCLUSION}

It is very clear that the properties such as Tensile strength, Elongation at break, hardness, Sole flexing \& Abrasion Resistance of the trial are gradually decreased as compare to commercial control sample when we mix more than 70 PHR of chrome shavings in the composite. The Trial containing 50PHR to 70PHR of chrome shavings in the composite have meets the control parameters. So it is evident that for optimum property we can mix chrome shavings up to 70 PHR in the composite

\section{REFERENCES}

[1] S.Ponsubbiah,Dr.Sanjeev

Gupta,Dr.J.Jaisankar,Dr.K.Pandian \& Dr.R.Mohan"Preparation of shoe soling material from Leather Waste'IJRAT Vol 6 Sep 2018

[2] Srinivasan.T.S (1980).A sample survey conducted on availability of tannery solid waste in Tamilnadu.

[3] Balachandaran unni Nair,Raghava Rao.J,Sreeram K.J and Thanikaivelan.P(2002)"Green Route for the utilization of chrome shavings" Environmental science and Technology vol.36No.6pp1372-1376.

[4] Report of the meeting of the IULTCS Tannery wastes commission (1981).Waalwijk,Holland 9-11 May.

[5] T.P.Sastry,P.K.Sehal and T.Ramasami:Value added eco friendly products from tannery solid wastes.Journal of Environmental science \& engineering.

[6] 1 Ramasami T, Rao J R, Chandrababu N K, Parthasarathi K, Rao P G, Saravanan P, Gayathri R \& Sreeram K J,Beamhouse and tanning operations: Process chemistryrevisited, J Soc Leather Technol Chem, 83 (1999) 39-45.

[7] Mariappan, M, Environmental protection initiatives in Indian tanneries - A perspective view, Proc 30th 
Leath Res Ind GetTogether (CLRI, Chennai) 1997, 151-161.

[8] Suseela K, Parvathi M S \& Nandy S C, Chromium containing leather wastes, Leder, 34 (1983) 82-87.

[9] Manzo G, Fedele G \& Coluvcio A, Utilisation of shavings in chrome tannage, Cuio, 69 (1993) 6369.

[10] Cantera C S, Giuste M D \& Sofia A, Hydrolysis of chrome shavings: Application of collagen hydrolysate and acrylicprotein in post tanning operations, J Soc Leather TechnolChem, 81 (1997) 183-191.

[11] Cantera C S, Adding value to chrome shavings: hydrolysates as retanning materials, World Leather, 16 (2003) 27-29.

[12] Crispim A \& Mota M, Leather shavings treatment - An enzymatic approach, J Soc Leather Technol Chem, 87 (2003) 203.

[13] S.Ponsubbiah,S.Suryanarayana \& Dr.Sanjeev gupta"Composite from leather waste"IJLTEMAS vol VII,Issue III,March 2018.

[14] J.kanagaraj,K.C

Velappan,N.K.Chandrababu\&S.Sadullah "Solid waste generated in the Leather industry and its utilization for cleaner environment" Journal of scientific and Industrial research vol 65 July 2006,PP541-548 